\section{On the Formation of Weddellite in} Chamaecereus silvestrii, a Cactaceae Species from Northern Argentina

P. V. Monje $\mathrm{a}^{\mathrm{a}}$ and E. J. Baran ${ }^{\mathrm{b}}$

a Departamento de Biología y Bioquímica, Universidad Nacional del Sur, 8000-Bahía Blanca, Argentina

b Química Inorgánica (QUINOR), Facultad de Ciencias Exactas. Universidad Nacional de La Plata, C. Correo 962, 1900-La Plata, Argentina

Z.Naturforsch. 51c, 426-428 (1996); received November 21, 1995/February 21, 1996

Cactaceae, Chamaecereus silvestrii, Weddellite, Isolation, Infrared Spectrum

The isolation of well formed crystals of the biomineral weddellite (calcium oxalate dihydrate) from Chamaecereus silvestrii, a Cactaceae species found in the northern part of Argentina, is described. Infrared spectroscopic measurements allow an unambiguous characterization of the nature of the crystals. This is the first report of the presence of a biomineral in this plant species.

Although the existence of mineral formations in plants has been known since the 17th. century, the nature and meaning of the deposits have not concited great interest up to recent years.

Notwithstanding, a total comprehension of the distribution, development and especially the physiological significance of these mineral deposits has not yet been achieved (Arnott, 1982).

The three most common biominerals in higher plants are hydrated calcium oxalates, calcium carbonate and opal (hydrated silicon dioxide) (Arnott, 1982).

Although the presence of biominerals in Cactaceae has been reported (Arnott, 1982; McNair, 1932; Rivera and Smith, 1979), detailed studies and unambiguous characterization of the exact chemical nature of the isolated crystals are often missed.

Cactaceae are good models for studying the tolerance and response mechanisms of plants to overcome stress situations imposed by the absence of water and extreme temperature and salinity conditions of the environment.
In this context, we have initiated a series of studies devoted to the investigation of ionic transport mechanisms at membrane level in these type of plants, with Chamaecereus silvestrii (Speg.) Brit. and Rose, a dwarf-cactaceae found in some regions of the provinces of Tucumán and Salta (northern Argentina) (Kiesling, 1975; Backeberg, 1983). During the isolation process of protoplasts of photosynthetic cells from the reserve parenchyma, we could establish the existence of abundant quantities of a biomineral, in the form of great and very compact druses, present in the tissue of these plants.

As such crystalline formations have not been previously reported in this species, we have made a spectroscopic analysis of a number of samples of the biomineral which could be separated from the plant tissue, as described in the experimental part.

The infrared spectra of these samples allow to identify the crystalline material as weddellite (dihydrated calcium oxalate, $\mathrm{CaC}_{2} \mathrm{O}_{4} \cdot 2 \mathrm{H}_{2} \mathrm{O}$ ) by comparison with literature data (Babic-Ivancic et al., 1985; Varetti and Volponi, 1995). Spectra of samples obtained in three different and independent isolation experiments were identical. One of the obtained spectra is shown in Fig. 1.

This spectrum appears very well defined and free of spurious bands, showing the high purity of the biomineral. The two stretching vibrations of the carboxylate groups are found at 1645 and 1325 $\mathrm{cm}^{-1}$. The well-structured triplet observed at lower frequencies, with components at 777,611 and $519 \mathrm{~cm}^{-1}$, is difficult to assign. In this region one expects $\delta(\mathrm{O}-\mathrm{C}=\mathrm{O})$ deformations, $v(\mathrm{C}-\mathrm{C})$ stretchings and torsional modes of the water molecules (Nakamoto, 1978). The very broad and poorly defined band located at $3471 \mathrm{~cm}^{-1}$ with a shoulder at $c a .3340 \mathrm{~cm}^{-1}$, is assigned to the $\mathrm{O}-\mathrm{H}$ stretching vibrations of the water molecules. The position of these bands point to the presence of hydrogen bridges of intermediate length (Siebert, 1966). The deformational mode of the water molecules is evidently overlapped by the strong 1645 $\mathrm{cm}^{-1}$ band.

Reprint requests to Prof. Dr. E. J. Baran. 


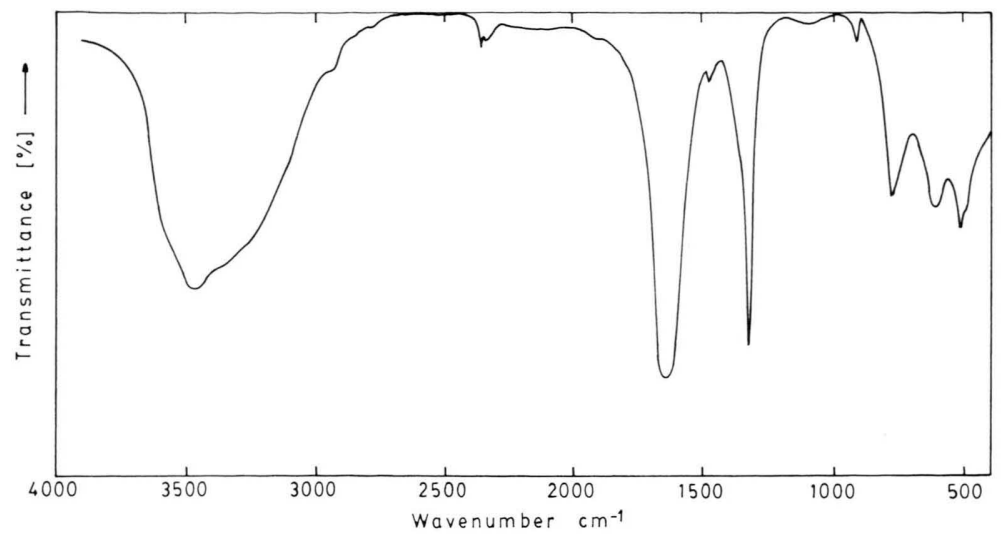

Fig. 1. Infrared spectrum of weddellite isolated from Chamaecereus silvestrii.

The presence of weddellite crystals in this species is also interesting, because the dihydrate is the metastable form of the calcium oxalate hydrates (Frey-Wyssling, 1981) and, therefore, weddellite is less commonly found in plants than the stable modification, whewellite $\left(\mathrm{CaC}_{2} \mathrm{O}_{4} \cdot \mathrm{H}_{2} \mathrm{O}\right)$ (Arnott, 1982; McNair, 1932). But, these biominerals are always found as intracellular formations in specialized cells called crystal idioblasts (Arnott, 1982; Franceschi and Horner, 1980; Foster, 1956) which probably can control the type of crystal to be formed, as well as it development and morphology; that is to say, the cell controls physical and chemical parameters in such a way that a specific type of crystal is formed (Arnott, 1982).

\section{Experimental Part}

Small stems of Chamaecereus silvestrii, commercially available, were cultivated in the laboratory, under natural illumination at room temperature $\left(20^{\circ} \mathrm{C}\right)$ and irrigated with the usual water regimen which favors the adequate development of this type of plants. After a growing of $c a$. three months the stems attain an adequate length for the crystal extraction.

The hardest part of well developed stems ( $c a .10$ $\mathrm{cm}$ long and $1 \mathrm{~cm}$ in diameter) was selected to obtain the weddellite crystals. These stem fragments were thoroughly washed with distilled water. The short and fine thistles, together with the epidermis, were separated and the remaining material was washed again and cut in fine sheets perpendicularly to the main axis.
A standard enzymatic technique, usually used for the isolation of higher plant protoplasts (Cooking, 1972; Wagner et al., 1978; Ruesink, 1980) was adapted for the isolation of the biomineral. The tissue sheets ( $c a .7-8 \mathrm{~g}$ ) were immersed in $10 \mathrm{ml}$ of an enzyme mixture containing $0.8 \mathrm{~m}$ of manitol, $0.1 \%(\mathrm{w} / \mathrm{v})$ of bovine serum albumin, $1 \mathrm{~mm} \mathrm{CaCl}_{2}$, $0.1 \mathrm{~mm}$ ascorbic acid, $5 \mathrm{~mm} \operatorname{MES}(2-(\mathrm{N}$-morpholino)ethanesulfonic acid)/KOH, $\mathrm{pH} 5.6$, and addition of $2 \%(\mathrm{w} / \mathrm{v})$ cellulase $\mathrm{Y}-\mathrm{C}$ (Seishin Pharm. Co., Tokyo) and $1 \%(w / v)$ pectolyase Y-23 (Seishin Pharm. Co., Tokyo) (Nagata and Ishi, 1979; Zanello et al., 1988). The incubation of the tissue was performed working at room temperature, during 30 minutes. During the digestion of the cellular walls, the tissue is degraded and the crystals of the biomineral were liberated. The supernatant fraction (containing free protoplasts, chloroplasts and debris) was discarded and the weddellite crystals, which can be easily visualized, could be separated without difficulties from the other materials, due to their higher sedimentation velocity, related to its higher density. They were purified by successive washing with distilled water.

Abundant crystal formation was always detected in the older tissues (i.e., those belonging to the inferior half of the stems). Incubation of recently developed parts of the plant never showed the presence of crystals and also microscopic observation of such tissues revealed its absence. Nevertheless, it is possible that in these younger tissues the biominerals were too small (crystal sand) to be easily detected. 
The infrared spectra were obtained by means of a Bruker IFS 66 spectrophotometer in the spectral range between 4000 and $400 \mathrm{~cm}^{-1}$, using the $\mathrm{KBr}-$ pellet technique ( $c a .4 \mathrm{mg}$ of the powdered crystal sample dispersed in $100 \mathrm{mg}$ of $\mathrm{KBr}$ ).

Arnott H. J. (1982), Three systems of biomineralization in plants with comments on the associated organic matrix. In: Biological Mneralization and Demineralization, (G. H. Nancollas ed.). Springer Verlag, Berlin, pp. 199-218.

Babic-Ivancic V., Füredi-Milhofer H., Purgaric B., Brnicevic N. and Despotovic Z. (1985), Precipitatin of calcium oxalates from high ionic strength solutions. J. Cryst. Growth 71, 655-663.

Backeberg C. (1983), Die Cactaceae. Vol. II, G. Fischer Verlag, Stuttgart, pp. 1336-1338.

Cooking E. C. (1972), Plant cell protoplasts. Isolation and development. An. Rev. Plant Physiol. 23, 29-50.

Foster A. S. (1956), Plant idioblasts: remarkable example of cell specialization. Protoplasma 46, 184-193.

Franceschi V. L. and Horner, jr. H. T. (1980), Calcium oxalate crystals in plants. Bot. Rev. 4, 361-427.

Frey-Wissling A. (1981), Crystallography of the two hydrates of crystalline calcium oxalates in plants. Am. J. Bot. 68, 130-141.

Kiesling R. (1975), Los géneros de Cactaceae de Argentina. Bol. Soc. Argent. Bot. 16, 107-227.

McNair J. B. (1932), The interrelation between substances in plants: essential oils and resins, cyanogen and oxalate. Am. J. Bot. 19, 255-271.

\section{Acknowledgements}

This work was supported by the "Consejo Nacional de Investigaciones Científicas y Técnicas de la República Argentina”.

Nagata T. and Ishi S. (1979), A rapid method for isolation of mesophyll protoplasts. Canad. J. Bot. 67, $1920-1923$.

Nakamoto K. (1978), Infrared and Raman Spectra of Inorganic and Coordination Compounds, 3rd. Edit. J. Wiley, New York, pp. 233-236.

Rivera E. R. and Smith B. N. (1979), Crystal morphology and ${ }^{13} \mathrm{C} /{ }^{12} \mathrm{C}$ composition of solid oxalate in Cacti. Plant Physiol. 64, 966-970.

Ruesink A. (1980), Protoplasts of plant cells. Methods in Enzymology 69, 69-84.

Siebert H. (1966), Anwendungen der Schwingungsspektroskopie in der Anorganischen Chemie, Springer Verlag, Berlin, pp. 87-93.

Varetti E. L. and Volponi C. R. (1995), Characterization of crystals in plant cells using FTIR microspectroscopy. Appl. Spectr. 49, 537-539.

Wagner G. J., Butcher H. C. and Siegelman H. W. (1978), Plant protoplasts. A useful tool for plant research and student instruction. Bioscience 28, 95-101.

Zanello L. P., Curvetto N. R. and Barrantes F. J. (1988), Rapid method for isolation and purification of protoplasts from epidermal tissue of vicia faba L. leaves. J. Appl. Microbiol. Biotechnol. 4, 275-283. 